\title{
Quercetin and quercetin 3-O-glycosides from Bauhinia longifolia (Bong.) Steud. show anti-Mayaro virus activity
}

\author{
Alda E dos Santos ${ }^{1}$, Ricardo M Kuster ${ }^{1}$, Kristie A Yamamoto ${ }^{3}$, Tiago S Salles ${ }^{3}$, Renata Campos², \\ Marcelo DF de Meneses ${ }^{2}$, Márcia R Soares ${ }^{3}$ and Davis Ferreira ${ }^{2,4^{*}}$
}

\begin{abstract}
Background: The arthropod-borne Mayaro virus (MAYV) causes 'Mayaro fever', a disease of medical significance, primarily affecting individuals in permanent contact with forested areas in tropical South America. Recently, MAYV has attracted attention due to its likely urbanization. Currently, there are no licensed drugs against most mosquito-transmitted viruses. Here, we investigated the in vitro anti-MAYV activity of the flavonoids quercetin and its derivatives from the Brazilian shrub Bauhinia longifolia (Bong.) Steud.

Methods: Flavonoids were purified by chromatographic fractionation from leaf extracts of B. longifolia and chemically identified as quercetin and quercetin glycosides using spectroscopic techniques. Cytotoxicity of purified flavonoids and of EtOAc- and $n-\mathrm{BuOH}$-containing flavonoid mixtures was measured by the dye-uptake assay while their antiviral activity was evaluated by a virus yield inhibition assay.

Results: The following flavonoids were purified from B. longifolia leaves: non-glycosylated quercetin and its glycosides guaijaverin, quercitrin, isoquercitrin, and hyperin. EtOAc and $n-\mathrm{BuOH}$ fractions containing these flavonoids demonstrated the highest antiviral activity of all tested substances, while quercetin had the highest antiviral activity amongst purified flavonoids. Quercetin, EtOAc, or $n-\mathrm{BuOH}$ fractions inhibited MAYV production by more than $90 \%$ at $25 \mathrm{\mu g} / \mathrm{mL}$, displaying a stronger antiviral effect than the licensed antiviral ribavirin. A mixture of the isomers isoquercitrin and hyperin had a modest antiviral effect $\left(I_{90}=104.9\right)$, while guaijaverin and quercitrin did not show significant antiviral activity.
\end{abstract}

Conclusions: B. longifolia is a good source of flavonoids with anti-Mayaro virus activity. This is the first report of the activity of quercetin and its derivatives against an alphavirus.

Keywords: Bauhinia longifolia, Flavonoids, Quercetin derivatives, Antiviral, MAYV

\section{Background}

Brazil remains extensively covered by tropical forests and other natural ecosystems, despite high deforestation rates. A critical effect of deforestation is the introduction of new viruses into urban areas, providing ideal conditions for the development of several arboviruses [1]. Indeed, more than 200 species of arboviruses have been isolated in urban areas in Brazil, including approximately

\footnotetext{
* Correspondence: davisf@micro.ufr.j.br

${ }^{2}$ Microbiology Institute, Virology Department, Federal University of Rio de Janeiro, Rio de Janeiro, Brazil

${ }^{4}$ National Institute of Science and Technology for Structural Biology and Bioimaging, Rio de Janeiro, Brazil

Full list of author information is available at the end of the article
}

40 species causing diseases in humans, including the Mayaro fever [2], which is caused by the Mayaro virus (MAYV).

Mayaro virus (MAYV), a member of the Togaviridae family (genus Alphavirus), was first isolated in Trinidad in 1954 [3]. MAYV is closely related to Chikungunya and other alphaviruses, producing an acute, self-limited denguelike illness that is accompanied by long-lasting arthralgia $[4,5]$. Since the initial description of MAYV, several small outbreaks of Mayaro fever have been reported in rural communities in northern Brazil and in eastern Bolivia [6-8]. Moreover, MAYV antibodies have been detected in human and animal populations in Bolivia, Brazil, Colombia, Panama, Peru, Surinam, Trinidad and Tobago, 
Venezuela, French Guiana, and Mexico, suggesting increasing viral dissemination [9-15].

Antibodies against MAYV are often detected in certain species of monkeys, which are likely to be the main natural reservoir of the virus [16], while the main vectors are mosquitoes of the Haemagogus species, although Aedes species might also act as MAYV vectors. Thus, it is possible that, under appropriate conditions, MAYV can be transmitted in urban areas [1].

In Brazil, MAYV is endemic to the Amazon region, but cases of the disease have been observed elsewhere. Mayaro fever outbreaks occurred in central regions in Brazil, namely Itarumã (Goiás state) and in Peixe (Tocantins state) [17], in 1987 and 1991, respectively. Also, three cases of Mayaro fever were reported in Mato Grosso state [18]. Also, a report from 2010 describes a young French tourist being diagnosed with MAYV after visiting the Brazilian Amazon [19]. The importance of controlling MAYV spread or seeking treatment for the virus infection extends beyond the Amazon region. As an alphavirus, MAYV can serve as a model for other important viruses such as Chickungunya virus, an emerging virus that has been spread in Europe recently [20-22].

Currently, about 40 antiviral drugs are available for clinical use, mainly targeting HIV and a small number of other viruses [23]. Nevertheless, research efforts to explore the potential of natural products as sources of novel low toxicity and high selectivity antiviral substances have increased lately [24]. These natural products, also called plant-derived products, are very attractive when compared to synthetic molecules. This is true mainly because of the low cytotoxicity, the rapid degradation in the environment, and because of the complexity of the chemistry in these products, that should limit resistance and increase the applicability of use, such as vector control studies $[25,26]$. Because there are many approaches for the use of natural products, the modes of action or the active components they contain and the metabolic pathways they interact with must be studied. This can be accomplished initially by in vitro studies such as the cell culture approach in this paper.

Shrubs from the Bauhinia (Fabaceae) genus are found in tropical regions of Asia, Africa, and Central and South America. In Brazil, these plants are known as 'pata-devaca' (cow's foot) because of their leaf shape [27]. Tea made from B. longifolia and B. forficata leaves is consumed in certain regions of Brazil [28] for its anti-diabetic properties (according to Brazilian folk medicine). Flavonoids, mainly kaempferol and quercetin derivatives, are commonly found in plants in the Bauhinia genus [29]. Flavonoids have known antiviral potential, and a number of reports describe their different antiviral mechanisms, including inhibition of infectivity and replication, depending on the target virus [30].
In view of this interesting scenario, in the present study we evaluated the antiviral activity of Bauhinia longifolia (Bong.) Steud. against MAYV replication in Vero cells. We also determined the selective antiviral activity of purified quercetin and quercetin glycoside derivatives, as well as of leaf extracts rich in these flavonoids.

\section{Methods}

\section{Plants, cells and viruses}

In this study, leaves from wild specimens of Bauhinia longifolia (Bong.) Steud. collected in the municipality of Luz, Minas Gerais state (Brazil) were used. Plant species authentication was performed by comparison with herbarium specimens from the Institute of Biological Sciences (Federal University of Minas Gerais, Belo Horizonte, Brazil), where a voucher specimen (BHCB 18778) was deposited.

Vero cells (African green monkey kidney, ATCC CCL-81) were grown at $37^{\circ} \mathrm{C}$ with $5 \% \mathrm{CO}_{2}$, in Dulbecco's modified Eagle's medium (DMEM) (Life Technologies, USA) supplemented with $5 \%$ fetal bovine serum (Cultilab, BRA), $50 \mathrm{IU} / \mathrm{mL}$ of penicillin, and $50 \mu \mathrm{g} / \mathrm{mL}$ of streptomycin (Sigma-Aldrich, USA). Mayaro viruses (ATCC VR-66, lineage TR 4675) were propagated in Vero cells and viral stocks in $10 \%$ glycerol were kept at $-70^{\circ} \mathrm{C}$. Virus titer was determined by plaque assay (described under 'Antiviral activity assay').

\section{Extraction, fractionation, and purification of quercetin derivatives}

Air-dried and powdered leaves $(1.5 \mathrm{Kg})$ were extracted with $\mathrm{MeOH}$ at room temperature for 7 days. Pooled methanol extracts were filtered and concentrated under reduced pressure to produce a crude extract $(95 \mathrm{~g})$, which was diluted in $\mathrm{MeOH}-\mathrm{H}_{2} \mathrm{O}$ to a ratio of 9:1, and then extracted successively with $n$-hexane, $\mathrm{CH}_{2} \mathrm{Cl}_{2}$, EtOAc, and $n-\mathrm{BuOH}$.

EtOAc (7 g) and $n-\mathrm{BuOH}(6 \mathrm{~g})$ fractions were chromatographed separately on amberlite XAD-16 columns $(2 \mathrm{~m} \times 8 \mathrm{~cm}$ i.d.) (Sigma-Aldrich). Aqueous methanol solutions (from $0 \%$ to $100 \%$, with $10 \%$ increments) were used as the mobile phase, and 11 fractions were collected for each extract (fractions A1-A11 and B1-B11, for EtOAc and $n-\mathrm{BuOH}$, respectively). After thin layer chromatography (TLC) analysis, selected fractions were pooled in three groups: F1, including fractions A6-A9 (4.5 g); F2, including fractions A10-A11 (0.9); and F3, including fractions B6-B11 (1.9).

F1 and F3 were chromatographed separately on Sephadex LH-20 columns ( $30 \mathrm{~cm} \times 45 \mathrm{~mm})$ (Sigma-Aldrich) with $\mathrm{MeOH}-\mathrm{H}_{2} \mathrm{O}(1: 1)$ as the mobile phase. F1 chromatography yielded fractions containing guaijaverin (1) and quercitrin (3), F2 fractions contained aglycon quercetin 
(2), and F3 fractions contained a mixture of the isomers isoquercitrin (4a) and hyperin (4b).

\section{Reverse-phase HPLC-DAD and TLC analyses}

HPLC-DAD (High Performance Liquid Chromatography with Diode Array Detector) and TLC (Thin Layer Chromatography) were used to analyze the chemical composition of EtOAc and $n-\mathrm{BuOH}$ fractions described above. The mobile phase of HPLC-DAD analysis consisted of (A) $1 \%$ phosphoric acid in water or (B) $1 \%$ phosphoric acid in methanol. Gradients used were: $0-15$ min $50-$ $70 \%$ of $\mathrm{B}$ followed by $15-25 \mathrm{~min} 70-100 \%$ of $\mathrm{B}$. The flow rate was $1 \mathrm{~mL} / \mathrm{min}$ and the injection volume $20 \mu \mathrm{L}$. The UV-vis spectra were recorded from 254 to $400 \mathrm{~nm}$, with detection at 254 and $365 \mathrm{~nm}$. TLC was performed on silica gel Plates $60 \mathrm{~F}_{254}$ (Merck, $20 \times 20 \mathrm{~cm}, 0.5 \mathrm{~mm}$ thickness), using ethyl acetate-methanol-water-acetic acid (8:1:0.5:0.5) as eluent. After elution, TLC plates were observed under $254 \mathrm{~nm}$ UV light and then sprayed with solutions of NP (2-aminoethyldiphenylborinate 1\% in methanol) and PEG-400 (polyethylene glycol 5\% in ethanol) (both by Sigma-Aldrich, USA) before examination under $365 \mathrm{~nm}$ UV light. The presence of sugars was confirmed by acid hydrolysis of glycosides on TLC plates, and the sugar composition was inferred by comparison with standards of each of the following sugars: arabinose, xylose, galactose, glucose, and rhamnose (Sigma-Aldrich, USA). Final compound identification was performed by extensive $1 \mathrm{D}$ - $\left({ }^{1} \mathrm{H}\right.$ and $\left.{ }^{13} \mathrm{C}\right)$ and $2 \mathrm{D}$ (COSY, HMBC, HSQC) NMR experiments, ESI-MS, UV spectral analysis, and by comparison with literature values.

\section{Cytotoxicity and antiviral activity assays}

Cytotoxicity analysis of B. longifolia-derived flavonoids, EtOAc and $n-\mathrm{BuOH}$ fractions, was performed using a dye-uptake method modified from Borenfreund and Puerner [31]. Briefly, confluent cultures of Vero cells in 96-well microplates were treated with culture media containing different concentrations of the substances being tested. After 24 hours, the culture medium was replaced by a solution of $50 \mu \mathrm{g} / \mathrm{mL}$ neutral red and the cells were incubated for 3 hours, at $37^{\circ} \mathrm{C}, 5 \% \mathrm{CO} 2$. Cells were then fixed with $20 \%$ formaldehyde and extracted with $50 \%$ methanol and $1 \%$ acetic acid, before measurement of absorbance at $\lambda 490 \mathrm{~nm}$, using a spectrophotometer, to detect neutral red incorporation by living cells. Absorbance results were used to calculate, by regression analysis, the concentrations of the tested substances capable of reducing cell viability by $50 \%$ and $90 \%$ relative to controls $\left(\mathrm{CC}_{50}\right.$ and $\mathrm{CC}_{90}$, respectively).

Antiviral activity was evaluated using a virus yield inhibition assay. Briefly, confluent cell monolayers grown in 24-well plates were infected with MAYV (multiplicity of infection $=0.1$ ) for 1 hour, then rinsed with PBS and treated for 24 hours (at $37^{\circ} \mathrm{C}$ and $5 \% \mathrm{CO}_{2}$ ) with different concentrations $(0-100 \mu \mathrm{g} / \mathrm{ml})$ of flavonoids or extracts diluted in culture medium. After treatment, culture supernatants were recovered and used for titration of extracellular infectious virus particles. For virus titration, confluent cell monolayers in 24-well plates were infected with serial dilutions of recovered supernatants for 1 hour at $37^{\circ} \mathrm{C}, 5 \% \mathrm{CO}$. After inoculum removal, cells were rinsed with $\mathrm{PBS}$ and the monolayer was incubated with fresh medium with $2 \%$ carboxymethylcellulose (SigmaAldrich, USA) for 48 hours at $37^{\circ} \mathrm{C}, 5 \% \mathrm{CO} 2$. Finally, cells were fixed with $20 \%$ formaldehyde and stained with $0.5 \%$ crystal violet in $20 \%$ ethanol, and viral plaques were counted. Ribavirin (Sigma-Aldrich, USA) was used as positive control for MAYV replication inhibition. For each substance or extract, $\mathrm{IC}_{50}$ and $\mathrm{IC}_{90}$ values were calculated and used to obtain a selectivity index (SI), expressed as the ratio $\mathrm{CC}_{50} / \mathrm{IC}_{50}$, and to estimate relative potency (RP) as the ratio between ribavirin (reference substance) $\mathrm{IC}_{90}$ and the tested substance's $\mathrm{IC}_{90}$. Results were presented as mean inhibitory/cytotoxic concentration $\pm \mathrm{SD}$, and $t$-tests were used to evaluate the statistical significance of treatments relative to controls. P-values $<0.05$ were considered statistically significant.

\section{Results}

Flavonoids quercetin and quercetin derivatives are found in extracts of $B$. longifolia leaves

HPLC-DAD analysis revealed that EtOAc and $n-\mathrm{BuOH}$ fractions from the methanol extract of $B$. longifolia show similar chemical profiles (Figure 1A), displaying varying proportions of five major compounds having UV absorption typical of flavonoids (Figure 1B).

Using NMR, ESI-MS, and UV spectral analyses, the compounds in profile peaks from Figure 1A were identified as: guaijaverin (quercetin-3-O- $\alpha$-arabinoside, peak 1) [32]; quercetin (peak 2) [33]; quercitrin (quercetin-3-O- $\alpha$-rhamnoside, peak 3) [34]; isoquercitrin (quercetin-3-O- $\beta$-glucoside, peak 4a); and hyperin (quercetin-3-O-galactoside, peak 4b) [35]. Figure 2 shows the chemical structure of these compounds, and Table 1 shows their corresponding HPLC-DAD and ESI-MS data.

The simplicity of the foliar flavonoid metabolism of $B$. longifolia is revealed by the absence of kaempferol derivatives (commonly found in the genus) and by the identification of quercetin derivatives only. Furthermore, the presence of quercetin 3-O-monoglycosides suggests the effective action of glycosilation enzymes such as 3-Otransferases [36].

\section{Cytotoxicity and antiviral activity}

Quercetin, EtOAc, and $n-\mathrm{BuOH}$ fractions inhibited MAYV replication in Vero cells in a dose-dependent 


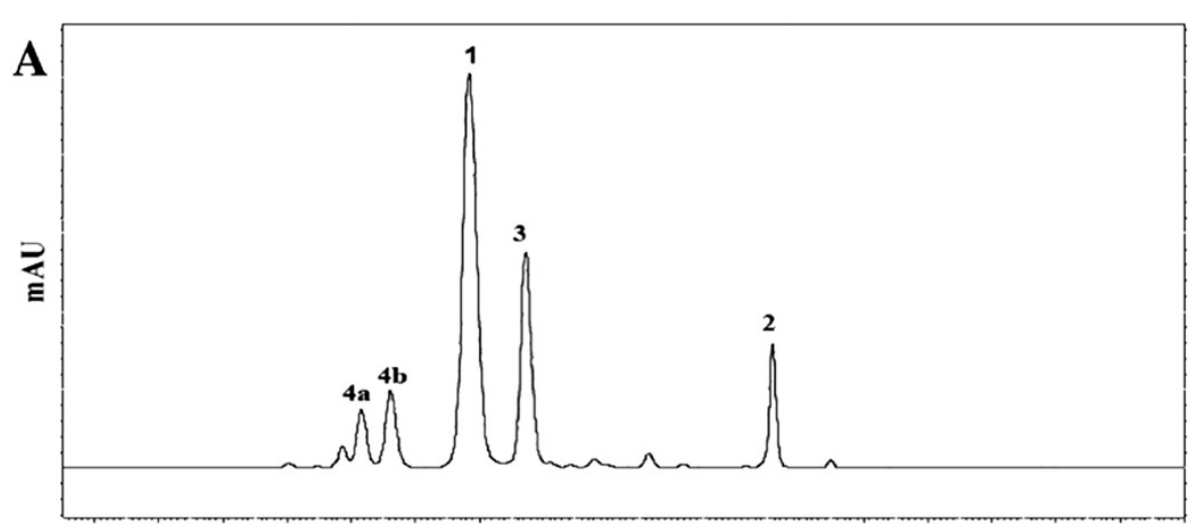

Retention Time

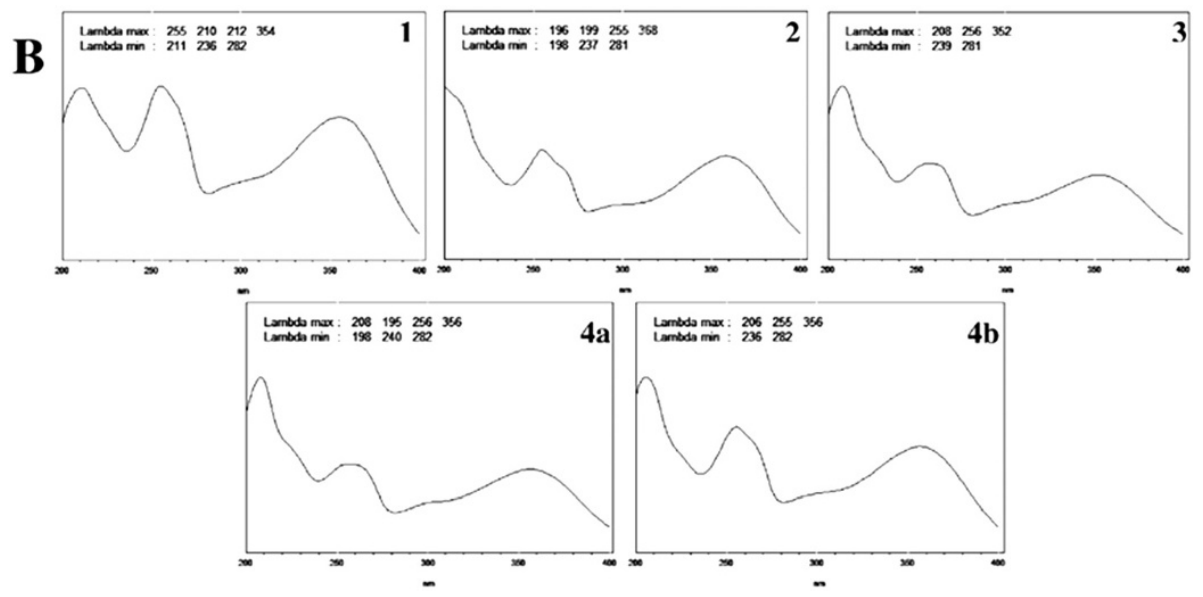

Figure 1 HPLC-DAD analysis detects flavonoids in extracts from B. longifolia. (A) $365 \mathrm{~nm}$ diode array chromatogram of EtOAc fraction from the leaves of $B$. longifolia. (B) UV spectra of quercetin derivatives present in the EtOAc fraction.

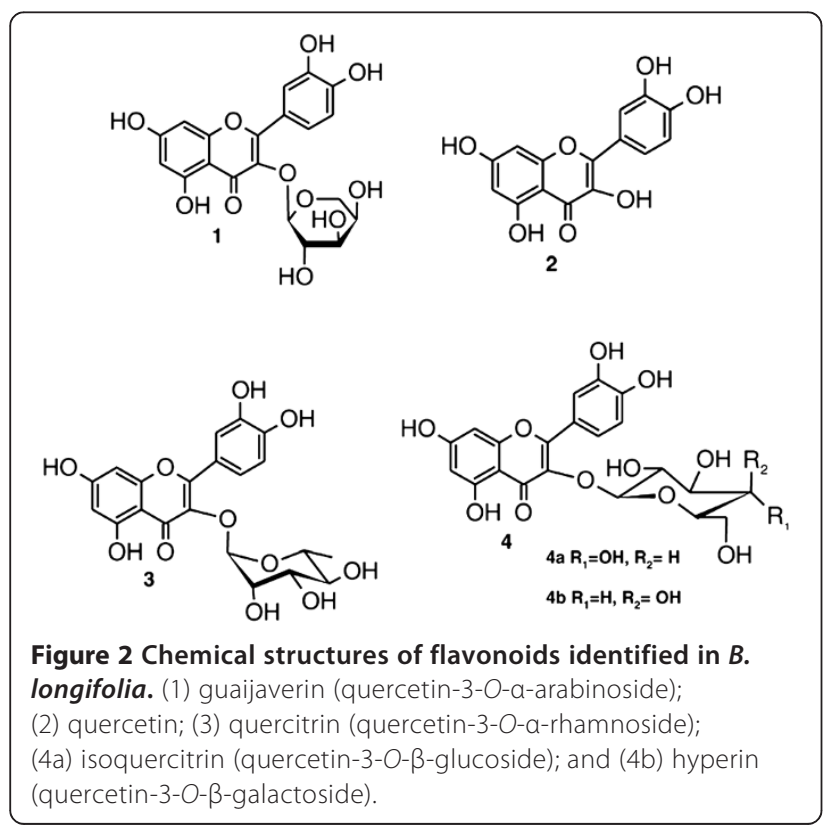

manner, with more than $90 \%$ inhibition at $25 \mu \mathrm{g} / \mathrm{mL}$ (Table 2 and Figure 3). In contrast, mixtures of the isomers isoquercitrin (4a) and hyperin (4b) or the antiviral ribavirin were much less potent inhibitors of MAYV replication, with $\mathrm{IC}_{90}$ values above $100 \mu \mathrm{g} / \mathrm{mL}$ (Table 2 and Figure 3). The monoglycosides guaijaverin and quercitrin did not show significant antiviral activity in the concentrations tested here (Table 2). EtOAc had the highest

Table 1 HPLC-DAD and ESI-MS data for quercetin derivatives from the leaves of $B$. longifolia

\begin{tabular}{|c|c|c|c|c|}
\hline Compound & Name & $\begin{array}{l}t_{\mathrm{R}} \\
(\min )\end{array}$ & $\begin{array}{l}{[\mathrm{M}-\mathrm{H}]} \\
(\mathrm{m} / \mathrm{z})\end{array}$ & $\begin{array}{l}\lambda_{\max } \\
(\mathrm{nm})\end{array}$ \\
\hline 1 & Guaijaverin & 12.7 & 433 & 255,354 \\
\hline 2 & Quercetin & 22.1 & 301 & 255,368 \\
\hline 3 & Quercitrin & 14.4 & 447 & 256,352 \\
\hline $4 a$ & Isoquercitrin & 9.3 & 463 & 256,356 \\
\hline $4 b$ & Hyperin & 10.2 & 463 & 255,356 \\
\hline
\end{tabular}


Table 2 Cytotoxicity and anti-MAYV activity of purified quercetin and its derivatives EtOAc and $n$-BuOH extracts, containing equal parts of these compounds

\begin{tabular}{|c|c|c|c|c|c|c|}
\hline Substance & $\begin{array}{l}\mathrm{CC}_{50}^{\mathrm{a}} \\
\mu \mathrm{g} / \mathrm{ml}\end{array}$ & $\begin{array}{l}\mathrm{CC}_{90}^{\mathrm{a}} \\
\mu \mathrm{g} / \mathrm{ml}\end{array}$ & $\begin{array}{l}I_{50}^{b} \\
\mu \mathrm{g} / \mathrm{ml}\end{array}$ & $\begin{array}{l}I_{90}^{b} \\
\mu \mathrm{g} / \mathrm{ml}\end{array}$ & $\mathrm{SI}^{\mathrm{c}}$ & $\mathrm{RP}^{\mathrm{d}}$ \\
\hline Guaijaverin & $795 \pm 54$ & $53 \pm 5$ & $>100$ & $>100$ & $\mathrm{Nd}$ & $\overline{\mathrm{nd}}$ \\
\hline Quercetin & $941 \pm 123$ & $43 \pm 4$ & $10 \pm 0.7$ & $19 \pm 0.7$ & 94 & 5 \\
\hline Quercitrin & $411 \pm 46$ & $41 \pm 4$ & $>100$ & $>100$ & $\mathrm{Nd}$ & nd \\
\hline Isoquercitrin + hyperin (1:1) & $265 \pm 19$ & $135 \pm 11$ & $59 \pm 0.2$ & $105 \pm 3$ & 4 & 1 \\
\hline EtOAc & $3116 \pm 405$ & $49 \pm 5$ & $5 \pm 0.3$ & $25 \pm 3.5$ & 623 & 4 \\
\hline$n-\mathrm{BuOH}$ & $418 \pm 47$ & $64 \pm 3$ & $3 \pm 0.2$ & $5 \pm 0.3$ & 208 & 20 \\
\hline Ribavirin & $523 \pm 42$ & $215 \pm 6$ & $62 \pm 4$ & $112 \pm 8$ & 8 & nd \\
\hline
\end{tabular}

a $-50 \%$ and $90 \%$ cytotoxic concentration.

b $-50 \%$ and $90 \%$ inhibitory concentration of viral replication.

c - Selectivity Index $=\mathrm{CC}_{50} / \mathrm{IC}_{50}$.

d - Relative Potency $=$ standard $\mathrm{IC}_{90} /$ substance $\mathrm{IC}_{90}$

nd - Not determined.

Selectivity Index (SI), which means that the concentration necessary for antiviral activity is much lower than that causing toxicity to these cells. A high SI is desirable, although much lower values warrant further investigation (see the value for ribavirin obtained under the conditions of this study). The Relative Potency was also calculated using ribavirin as a reference, and $n-B u O H$ was 20 times more powerful than ribavirin in these conditions. EtOAc (4) and quercetin (5) were also more powerful than ribavirin.

\section{Discussion}

In this study, the antiviral activity of quercetin and quercetin derivatives from $B$. longifolia on the replication of the arbovirus Mayaro was investigated. EtOAc and $n$ $\mathrm{BuOH}$ fractions containing a mixture of five flavonoids, including quercetin and its glycoside derivatives (guaijaverin, quercitrin, isoquercitrin, and hyperin, in different proportions) displayed stronger antiviral activities than those observed for the purified compounds and for the antiviral ribavirin, used as a positive control. Quercetin and the mixture of isoquercitrin and hyperin in identical proportions showed significant anti-MAYV activity while guaijaverin and quercitrin did not.

Importantly, quercetin displayed better selectivity towards MAYV and improved potency $(\mathrm{SI}=94$ and $\mathrm{RP}=5)$ when compared to the antiviral ribavirin $(\mathrm{SI}=8)$, clinically approved for the treatment of Hepatitis $\mathrm{C}$ virus

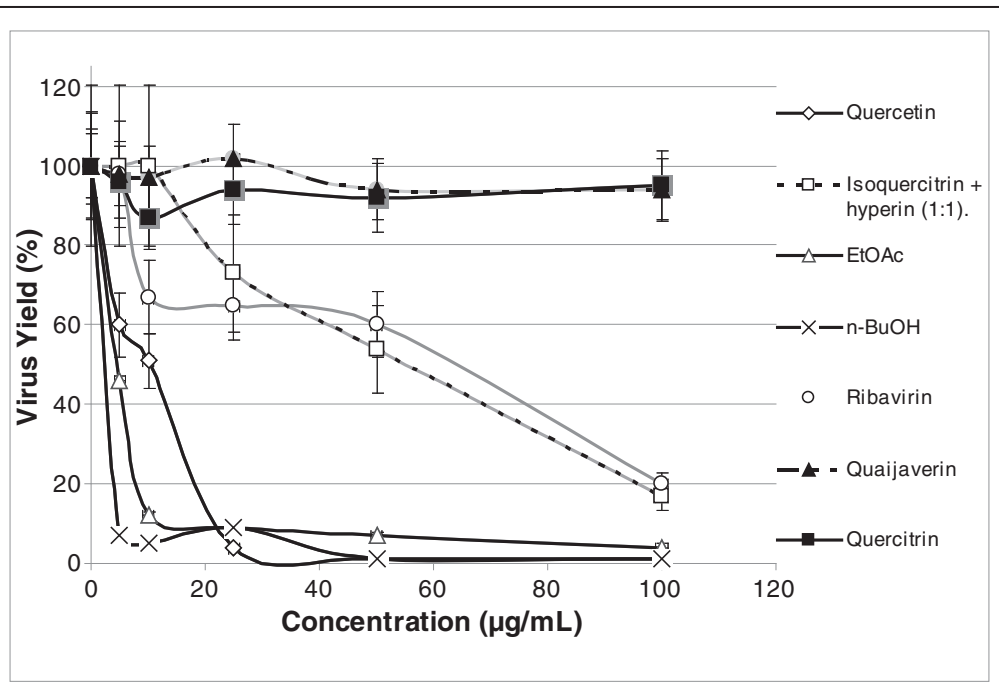

Figure 3 Anti-MAYV activity of different substances from B. longifolia. The anti-MAYV activity of purified flavonoids or EtOAc and $n-B u O H$ extracts from B. longifolia was evaluated by treating MAVV-infected cells with $0-100 \mu \mathrm{g} / \mathrm{ml}$ of these substances for $24 \mathrm{~h}$, and then staining for viral plaque counting. The graph shows the results from three independent experiments. Data are presented as mean\% virus yield (compared to untreated controls) \pm SD. 
infection and also experimentally shown to inhibit several other RNA and DNA viruses such as influenza, hepatitis B, poliomyelitis, measles, and smallpox [37]. Also, the antiviral activity of quercetin was considerably stronger and more selective than that of glycosilated quercetin derivatives, suggesting that glycosilation reduces the antiviral activity of quercetin against MAYV. In contrast, Yarmolinsky et al. [38] reported increased antiherpes simplex virus-1 (HSV-1) activity for the compounds rutin (quercetin-3-O-rutinoside), kaempferol-3-Orutinoside, and kaempferol-3-O-robinobioside compared to that of the respective non-glycosylated compounds (quercetin and kaempferol). The difference in the findings may be explained by the fact that MAYV and HSV1 are viruses with very different replication strategies.

The mixture of isoquercitrin and hyperin had antiMAYV activity similar to that displayed by ribavirin, but the Selectivity Index was lower (4). This was due to the higher toxicity of the isoquercitrin/hyperin mixture if compared to ribavirin. However, the Relative Potency for ribavirin and the isoquercitrin/hyperin were similar, suggesting possible synergism between these isomeric flavonoids. The absence of anti-MAYV activity for guaijaverin and quercitrin in the concentrations tested here suggests that 3-O-glycosilation with arabinose and rhamnose is particularly detrimental to the antiviral activity against MAYV. This is an interesting finding already under investigation by our group.

According to Gould and Lister [39], flavonoids protect the plant against infection by microorganisms. Therefore, it is not surprising that these compounds are effective in vitro against a wide array of viruses, including HSP-1, parainfluenza-3, influenza, and dengue virus type-2 (DENV-2) [40-43], even though the antiviral mechanism for quercetin has not yet been fully elucidated. Zandi et al. [42] suggested that quercetin might prevent DENV-2 replication by inhibiting viral RNA polymerase, in a similar mechanism to that described for silymarin, a flavonoid mixture effective against the hepatitis C virus [44]. Inhibition of viral RNA metabolism, through binding to virus RNA, is also the most likely mechanism of action of the flavonol kaempferol against the Japanese encephalitis virus (JEV) [45].

\section{Conclusions}

Our results show that B. longifolia is a valuable source of flavonoids with antiviral activity against the arbovirus MAYV. Although quercetin and its 3-O-glycosides are fairly common in plants, this is the first report of antiMAYV activity for these flavonoids. Our data are an important step in the evaluation of natural products as sources of novel drugs to be used in combination therapy, to circumvent drug resistance, or to replace currently used antivirals with unwanted cytotoxic effects.

\section{Competing interests}

The authors declare that they have no competing interests.

\section{Authors' contributions}

RMK and DF conceived and designed the study. AES collected plant material, performed all phytochemical experiments and wrote the initial draft of the manuscript. KAY and TSS performed cytotoxicity and viral yield inhibition assays. MDFM and RC revised the data and carried out statistical analyses. MRS provided invaluable discussions on the chemical data and antiviral chemistry. All authors read and approved the final manuscript.

\section{Acknowledgements}

The authors would like to thank CAPES, CNPq, FAPERJ, and INBEB for financial support. We thank Cléber Barreto for the NMR analysis and Ana Claudia Amaral for ESI-MS analysis.

\section{Author details}

${ }^{1}$ Natural Product Research Institute, Center of Health Sciences, Federal University of Rio de Janeiro, Rio de Janeiro, Brazil. ²Microbiology Institute, Virology Department, Federal University of Rio de Janeiro, Rio de Janeiro, Brazil. ${ }^{3}$ Chemistry Institute, Biochemistry Department, Federal University of Rio de Janeiro, Rio de Janeiro, Brazil. ${ }^{4}$ National Institute of Science and Technology for Structural Biology and Bioimaging, Rio de Janeiro, Brazil.

Received: 20 January 2014 Accepted: 12 March 2014

Published: 28 March 2014

\section{References}

1. Figueiredo LTM: Emergent arboviruses in Brazil. Rev Soc Bras Med Trop 2007, 40:224-229.

2. Rosa APAT, Vasconcelos PFC, Rosa JFST: An Overview Of Arbovirology In Brazil And Neighbouring Countries. Belém: Instituto Evandro Chagas; 1998.

3. Anderson CR, Downs WG, Wattley GH, Ahin NW, Reese AA: Mayaro virus: a new human disease agent. II. Isolation from blood of patients in Trinidad. Am J Trop Med Hyg 1957, 6:1012-1016.

4. Pinheiro FP, Freitas RB, Rosa JFT, Gabbay YB, Mello WA, LeDuc JW: An outbreak of Mayaro virus disease in Belterra, Brazil. I. Clinical and virological findings. Am J Trop Med Hyg 1981, 30:674-681.

5. Tesh RB, Watts DM, Russell KL, Damodaran C, Calampa C, Cabezas C, Ramirez G, Vasquez B, Hayes CG, Rossi CA, Powers AM, Hice CL, Chandler L, Cropp BC, Karabatsos N, Roehrig JT, Gubler DJ: Mayaro virus disease: an emerging mosquito-borne zoonosis in tropical South America. Clin Infect Dis 1999, 28:67-73.

6. Causey OR, Maroja OM: Mayaro virus: a new human disease agent. III. Investigation of an epidemic of acute febrile illness on the River Guana in Pará, Brazil, and isolation of Mayaro virus as causative agent. Am J Trop Med Hyg 1957, 6:1017-1023.

7. Schaeffer M, Gajdusek DC, Lema AB, Eichenwald $H$ : Epidemic jungle fevers among Okinawan colonists in the Bolivian rain forest. I. Epidemiology. Am J Trop Med Hyg 1959, 8:372-396.

8. Leduc JW, Pinheiro FP, Rosa APAT: An outbreak of Mayaro virus disease in Belterra, Brazil. II. Epidemiology. Am J Trop Med Hyg 1981, 30:683-688.

9. Groot H, Kerr JA, Sanmartin C, Vidales H: Antibodies to yellow fever and other arthropod-borne viruses in human residents of San Vicente de Chucuri, Santander, Colombia. Am J Trop Med Hyg 1959, 8:175-189.

10. Pinheiro FP, LeDuc JW: Mayaro Virus Disease. In The Arboviruses, Epidemiology And Ecology. Edited by Monath T. Boca Raton: CRC Press; 1998:138-148.

11. Tavares-Neto J, Freitas-Carvalho J, Nunes MR, Rocha G, Rodrigues SG, Damasceno E, Darub R, Viana S, Vasconcelos PFC: Serologic survey for yellow fever and other arboviruses among inhabitants of Rio Branco, Brazil, before and three months after receiving the yellow fever 17D vaccine. Rev Soc Bras Med Trop 2004, 37:1-6.

12. Torres JR, Russell KL, Vasquez C, Barrera R, Tesh RB, Salas R, Watts DM: Family cluster of Mayaro fever, Venezuela. Emerg Infect Dis 2004, 10:1304-1306.

13. Navarrete-Espinoza J, Gomez-Dantes H: Arbovirus causing hemorrhagic fever at IMSS. Rev Med Inst Mex Seguro Soc 2006, 44:347-353.

14. Mourão MPG, Bastos MS, Figueiredo RP, Gimaque JBL, Galusso ES, Kramer VM, Oliveira CMC, Naveca FG, Figueiredo LTM: Mayaro Fever in the city of Manaus, Brazil, 2007-2008. Vector Borne and Zoonotic Dis 2012, 12:42-46. 
15. Neumayr A, Gabriel M, Fritz J, Gunther S, Hatz C, Schimidt-Chanasit J, Blum J: Mayaro virus infection in traveler returning from Amazon Basin, Northern Peru. Emerg Infect Dis 2012, 18:695-696.

16. Cortez LP, Burlandy FM, Rebello MA: Efeito da tunicamicina sobre a replicação do vírus Mayaro em células de Aedes albopictus. Rev Ciênc Méd Biol 2003, 1:5-11.

17. Vasconcelos PFC, Rosa APAT, Pinheiro FP, Shope RE, Rosa JFST, Rodrigues SG, Dégallier N, da Rosa ES T: Arboviruses Pathogenic For Man In Brazil. In An Overview Of Arbovirology In Brazil And Neighbouring Countries. Edited by Rosa APAT, Vasconcelos PFC, Rosa JFST. Belém: Instituto Evandro Chagas; 1998:72-99.

18. Coimbra TLM, Santos CLS, Suzuki A, Petrella SMC, Bisordi I, Nagamori AH, Marti AT, Santos RN, Fialho DM, Lavigne S, Buzzar MR, Rocco IM: Mayaro virus: imported cases of human infection in São Paulo state, Brazil. Rev Inst Med Trop Sao Paulo 2007, 4:221-224.

19. Receveur MC, Grandadam M, Pistone T, Malvy D: Infection with Mayaro virus in a French traveller returning from the Amazon region, Brazil. Euro Surveill 2010, 18:1-4

20. Fischer D, Thomas SM, Suk JE, Sudre B, Hess A, Tjaden NB, Beierkuhnlein C, Semenza JC: Climate change effects on Chikungunya transmission in Europe: geospatial analysis of vector's climatic suitability and virus' temperature requirements. Int J Health Geogr 2013, 12:1-12.

21. Schaffner F, Bellini R, Petric D, Scholte EJ, Zeller $H$, Rakotoarivony LM: Development of guidelines for the surveillance of invasive mosquitoes in Europe. Paras Vectors 2013, 6:209-219.

22. Kampen H, Werner D: Out of the bush: the Asian bush mosquito Aedes japonicus japonicus (Theobald, 1901) (Diptera, Culicidae) becomes invasive. Paras Vectors 2014, 7:59-69.

23. Yasuhara-Bell J, Yuanan L: Marine compounds and their antiviral activities. Antiviral Res 2010, 86:231-240.

24. Newman DJ, Cragg GM: Natural products as sources of new drugs over the 30 years from 1981 to 2010. J Nat Prod 2012, 75:311-335.

25. George DR, Finn RD, Graham KM, Sparagano OAE: Present and future potential of plant-derived products to control arthropods of veterinary and medical significance. Parasit Vectors 2014, 7:1-12.

26. Politi FAS, Fiqueira GMF, Araújo AM, Sampieri BR, Mathias MIC, Szabó MPJ, Bechara GH, Santos LC, Vilegas W, Pietro RCLR: Acaricidal activity of ethanolic extract from aerial parts of Tagetes patula L. (Asteraceae) against larvae and engorged adult females of Rhipicephalus sanguineus (Latreille, 1806). Parasit Vectors 2012, 5:295-306.

27. Cechinel-Filho V: Chemical composition and biological potential of plants from the genus Bauhinia. Phytother Res 2009, 23:1347-1354.

28. Almeida ER, Guedes MC, Albuquerque JFC, Xavier H: Hypoglycemic effect of Bauhinia cheilandra in rats. Fitoterapia 2006, 77:276-278

29. Pizzolatti MG, Cunha Junior A, Szpoganicz B, Sousa E, Braz-Filho R, Schripsema J: Flavonóides glicosilados das folhas e flores de Bauhinia forficata (Leguminosae). Quim Nova 2003, 26:466-469.

30. Nijveldt RJ, van Nood EV, van Hoorn DEC, Boelens PG, van Norren K, van Leeuwen PAM: Flavonoids: a review of probable mechanisms of action and potential applications. Am J Clin Nutr 2001, 74:418-425.

31. Borenfreund $E$, Puerner JA: Toxicity determined in vitro by morphological alterations and neutral red absorption. Toxicol Lett 1985, 24:119-124.

32. Kalegari M, Miguel MD, Dias JFG, Lordello ALL, Lima CP, Miyazaki CMS, Zanin SMW, Verdam MCS, Miguel OG: Phytochemical constituents and preliminary toxicity evaluation of leaves from Rourea induta Planch. (Connaraceae). Braz J Pharm Sci 2011, 3:635-642.

33. Fossen T, Andersen OM: Spectroscopic Techniques Applied To Flavonoids. In Flavonoids: Chemistry, Biochemistry and Applications. Edited by Andersen OM, Markham KR. Boca Raton: Taylor \& Francis Group: 2006:37-142.

34. Piccinelli AL, Veneziano A, Passi S, Simone F, Rastrelli L: Flavonoids glycosides from whole cottonseed by product. Food Chem 2007 100:344-349.

35. Rodrigues ED, Silva DB, Oliveira DCR, Silva GVJ: DOSY NMR applied to analysis of flavonoid glycosides from Bidens sulphurea. Magn Reson Chem 2009, 47:1095-1100.

36. Davies KM, Schwinn KE: Molecular Biology and Biotechnology of Flavonoid Biosynthesis. In Flavonoids: Chemistry, Biochemistry and Applications. Edited by Andersen OM, Markham KR. Boca Raton: Taylor \& Francis Group; 2006:168-169.
37. Elia G, Belloli C, Cirone F, Lucente MS, Caruso M, Martella V, Decaro N, Buonavoglia C, Ormas P: In vitro efficacy of ribavirin against canine distemper virus. Antiviral Res 2008, 77:108-113.

38. Yarmolinsky L, Huleihel M, Zaccai M, Ben-Shabat S: Potent antiviral flavone glycosides from Ficus benjamina leaves. Fitoterapia 2012, 83:362-367.

39. Gould KS, Lister C: Flavonoids Functions In Plants. In Flavonoids: Chemistry, Biochemistry and Applications. Edited by Andersen OM, Markham KR. Boca Raton: Taylor \& Francis Group; 2006:416-417.

40. Orhan DD, Ozçelik B, Ozgen S, Ergun F: Antibacterial, antifungal, and antiviral activities of some flavonoids. Microbiol Res 2010, 165:496-504

41. Fan D, Zhou X, Zhao C, Chen H, Zhao Y, Gong X: Anti-inflammatory, antiviral and quantitative study of quercetin-3-O- $\beta-D-$ glucuronide in Polygonum perfoliatum L. Fitoterapia 2011, 82:805-810.

42. Zandi K, Teoh B, Sam SS, Wong PF, Mustafa MR, Abubakar S: Antiviral activity of four types of bioflavonoid against dengue virus type-2. Virol J 2011, 8:560.

43. Thapa M, Kim Y, Desper J, Chang KO, Hua DH: Synthesis and antiviral activity of substituted quercetins. Bioorg Med Chem Lett 2012, 22:353-356.

44. Wagoner J, Negash A, Kane OJ, Martinez LE, Nahmias Y, Bourne N, Owen DM, Grove J, Brimacombe C, McKeating JA, Pécheur El, Graf TN, Oberlies $\mathrm{NH}$, Lohmann V, Cao F, Tavis JE, Polyak SJ: Multiple effects of silymarin on the hepatitis C virus lifecycle. Hepatology 1912-1921, 2010:51.

45. Zhang T, Wu Z, Du J, Hu Y, Liu L, Yang F, Jin Q: Anti- Japanese-encephalitis-viral effects of kaempferol and daidzin and their RNA-Binding characteristics. PLoS One 2012, 7:e30259.

doi:10.1186/1756-3305-7-130

Cite this article as: dos Santos et al:: Quercetin and quercetin 3-Oglycosides from Bauhinia longifolia (Bong.) Steud. show anti-Mayaro virus activity. Parasites \& Vectors 2014 7:130

\section{Submit your next manuscript to BioMed Central and take full advantage of:}

- Convenient online submission

- Thorough peer review

- No space constraints or color figure charges

- Immediate publication on acceptance

- Inclusion in PubMed, CAS, Scopus and Google Scholar

- Research which is freely available for redistribution 